\title{
Comparison between Photovoltaic and Wind Turbine for Monetary and Non-monetary Costing
}

\author{
${ }^{1}$ RajmalJoshi.M, ${ }^{2}$ Aravind CV,${ }^{3}$ Dr.R.Dhanasekaran, ${ }^{4}$ Charles Raymond, ${ }^{5}$ Se Yong En \\ ${ }^{1}$ Research Scholar, ${ }^{2}$ Professor, ${ }^{3}$ Director Research \\ Deaprtment Of Electrical And Electronics Engineering \\ ${ }^{1}$ Sathyabama Institute Of Science and Technology,Chennai,Tamilnadu,India \\ ${ }^{2}$ School of Engineering ,Taylor's university,Selangor Malaysia \\ ${ }^{3}$ Director Research ,Syed Ammal Engineering College,Ramanathapuram ,Tamilnadu, India \\ ${ }^{4}$ Sarimuthu School of Engineering,Taylor's University, Malaysia \\ ${ }^{5}$ School Of Engineering,Taylor's University,Selangor, Malaysia \\ rajmaljoshi@gmail.com, aravind@ieee.org,rdhanashekar@yahoo.com
}

\begin{abstract}
This paper compares the photovoltaic and wind turbine farm supply of village in the area of Ayer Keroh, park linked to the grid of Malaysia. The research is done on an energetic economic method according to temperature, wind speed, solar irradiation, installed system with estimated cost and energy consumption solutions were found of time profile. Hence, this is done by using Homer Pro environment simulator. Certainly, the best solution had a minimum resources to the electric grid with a maximum integrated renewable energy. Financial and technical features results showed different configurations achieved for the supply of the area chosen. Thus, from the solutions obtained by the two systems we found that solar energy gives the best efficiency in harvesting renewable energy because that the photovoltaic farm suffers from less fluctuation due to the equatorial climate of Malaysia where the amount of sunlight and temperature remains mostly constant during the day. The necessary capital required to build this PV farm system comes to a total net present cost (NPC) of RM 2,520,391.00 with an operating cost of RM 579,887.00 per year and a negative cost of energy of RM0.05423 per $\mathrm{kWh}$. This shows that we are actually generating more than enough supply while earning cash from the grid. (Abstract)
\end{abstract}

Keywords-Cost; Homer pro; Grid; Optimization; Wind turbine farm; Photovoltaic Park

\section{INTRODUCTION}

Global warming concerns coupled with high demand in electricity and drove many countries to direct their interests to renewable energy such as solar power, photovoltaic energy, wind, tides wave and geothermal energy [1].

In order to improve the quality of the energy supply researches worked in increasing the efficiency of converting the photovoltaic and the electromechanically energy. Researchers focused on the field of wind and photovoltaic energy which are used as a substitute for the ordinary energy sources. These sources are considered to be the most promising in the field of green energy either decentralized through other sources of energy to power remote site or connected to the grid [2].

In this framework, current ideas aim to deliver electricity through the implementation of a wind turbine farm or photovoltaic park to a village that has an urban zone and an industrial site. Moreover, this area is provided with energy in a case of inadequate weather conditions by connecting it to the grid [3]. This system is designed through the analysis of the load during the year and capacity of the systems furthermore considering the renewable energy such as wind potential, solar radiation, and temperature in the site as the main power source then comes the ability to receive electricity from the grid when it's necessary [4]. According to the simulation results a solution was given including the technical and financial part of the simulated systems. In this paper two parts were fully discussed including firstly, the general description of the studied system. The second part focuses on the technical and economical valuation of the Homer pro-environment simulations [5].formatter will need to create these components, incorporating the applicable criteria that follow.

\section{SySTEM CONFIGURATION}

A software called Homer Pro is used in this paper which is a reliable simulation and optimization program used in the analysis and design of electric energy conversion systems either with decentralized to power remote or by connecting it to the power grid [6]. In our paper, a comparison of two power conversion system is made, Photovoltaic Park and wind turbine farm based on a double-fed induction generator which is connected to the grid as shown in Fig. 1a and Fig 1b. The objective of this comparison is to electrify a village in the region of Ayer Keroh. Hence, overproduction is injected back to the grid. Certainly, load, cost, design for each device used and meteorological parameters, emission, constraint, impact to the electrification are all involved in the selection and optimization of the chosen system [7]. 


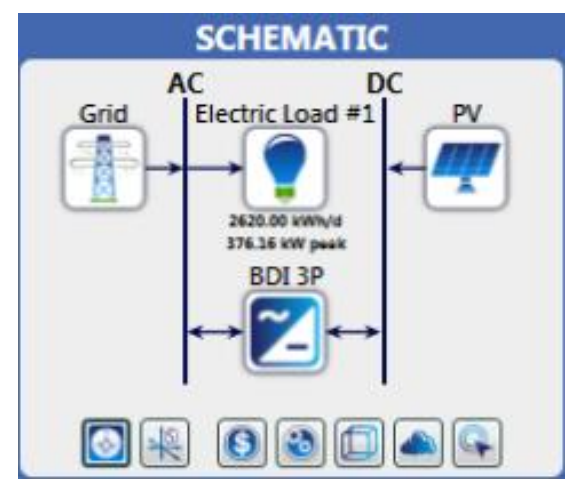

Fig. 1a. Photovoltaic Park Schematics.

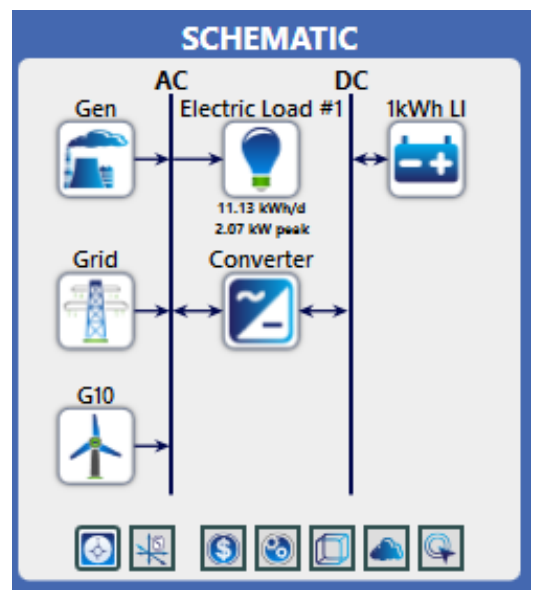

Fig. 1b. Wind Turbine Farm Schematics

\section{Site Statistics}

\section{A. Environmental Data and Load Profile}

1) Geological presentation of the examined site:

The location chosen for this study is Melaka shown in Fig. 2. It is one of the fourteen states in Malaysia located at the west island of the Malaysia. Melaka is a city filled with rich local history which includes diverse culture, structure and food as the outcome of past colonization of different foreign country. With its vast historical background, Melaka is considered as a potential tourism spot in Malaysia [8]. Using the whole Melaka as the targeted location reduces the accuracy of the data. Thus, the town, Ayer Keroh was selected to simulate in order to improve the accuracy of the simulation for the Homer pro software. The reason behind selecting Ayer Keroh as the location for this study is because that the Melaka Government built a solar farm within its vicinity [9]. The geographical location of Ayer Keroh is located proximally $2.268 \mathrm{~N}$, 102.283E shown in Fig. 3 [10]. The time zone of this location was GMT +08:00 according to the Greenwich Mean Time zone [11].

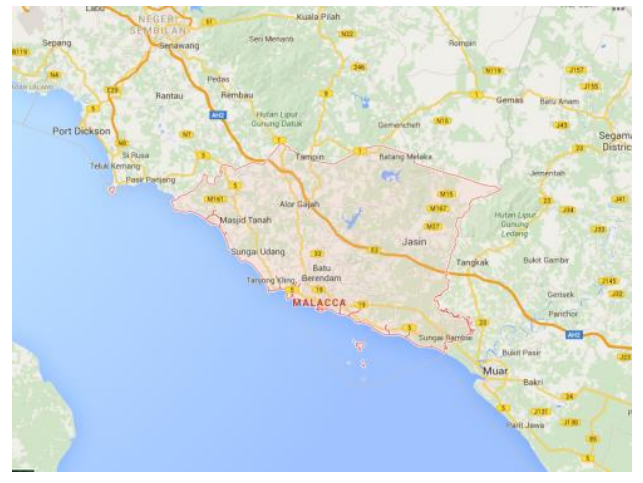

Fig. 2. Map of Melaka.

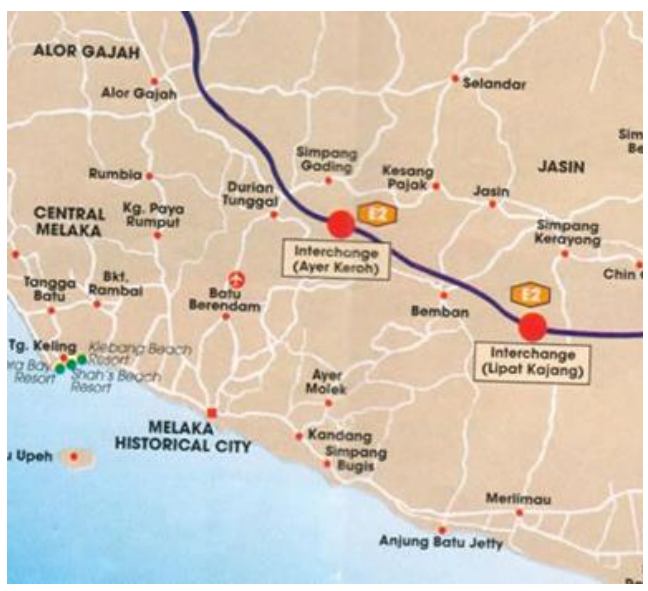

Fig. 3. Map of Ayer Keroh, Melaka [12].

\section{2) Wind data}

This wind data for this system is synthesized using the HOMER Pro software which collects data by itself by analysing the entered project location. Based on Fig. 4, we can observe the monthly average for wind speed. The average wind speed in Ayer Keroh, Melaka is calculated at $2.45 \mathrm{~m} / \mathrm{s}$ based on the values in Table I. The meteorology (wind) data are pull from NASA Surface meteorology and Solar Energy database automatically with the built in plugin from HOMER for the input coordinates of Ayer Keroh, Melaka (Latitude 2.268 / Longitude 102.283).

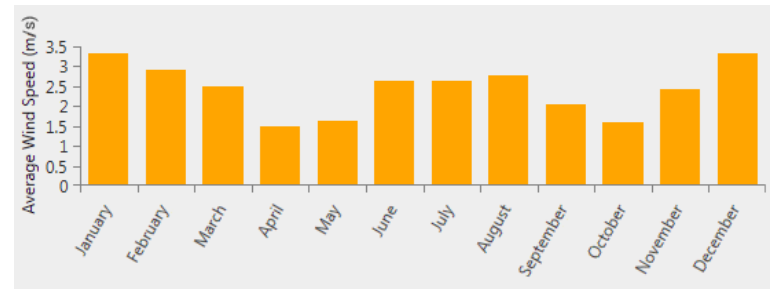

Fig. 4. Wind speed deviations across various months. 
TABLE I. Monthly AVERAGE Wind Speed Data

\begin{tabular}{|l|l|}
\hline \multicolumn{1}{|c|}{ Month } & Average (m/s) \\
\hline January & 3.330 \\
\hline February & 2.920 \\
\hline March & 2.500 \\
\hline April & 1.500 \\
\hline May & 1.640 \\
\hline June & 2.640 \\
\hline July & 2.640 \\
\hline August & 2.780 \\
\hline September & 2.060 \\
\hline October & 1.160 \\
\hline November & 2.420 \\
\hline December & 3.330 \\
\hline $\begin{array}{l}\text { Annual } \\
\text { Average }\end{array}$ & 2.45 \\
\hline
\end{tabular}

\section{3) Temperature data}

The average temperature data was collected for the purpose of determining the feasibility of solar farm through the study of effect of temperature on solar farms. The data was collected through Homer Pro software while actual data was obtained from NASA Surface meteorology and Solar Energy database through the energy source utility tools provided by Homer Pro software. The diagram in Fig. 5 presents the monthly average temperature data.

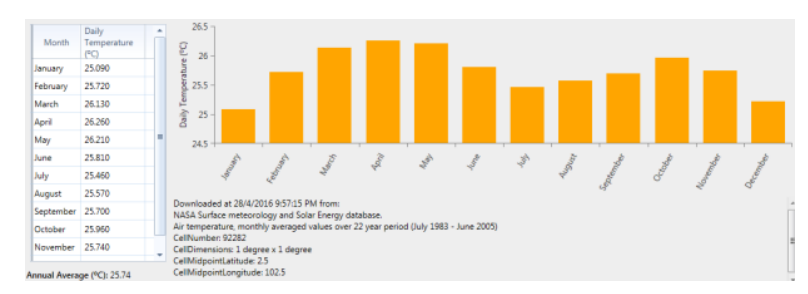

Fig. 5. Monthly Average Temperature Data

\section{4) Solar irradiation data}

The average temperature data was collected in order to determine the feasibility of solar farm as it varies the different amount of solar irradiation needed for the solar farm to function. The data was collected through Homer Pro software while actual data was obtained from NASA Surface meteorology and Solar Energy database through the energy source utility tools provided by Homer Pro Figure 6 displays the average solar irradiation data obtained using Homer Pro. The average solar irradiation obtained through the Homer Pro software was 4.68 $\mathrm{kWh} / \mathrm{m} 2 /$ day. Thus, the irradiation level qualifies for a solar farm.

5) Load profile of the chosen site

Load profile study was conducted to obtain the estimated load of the consumers around the site.

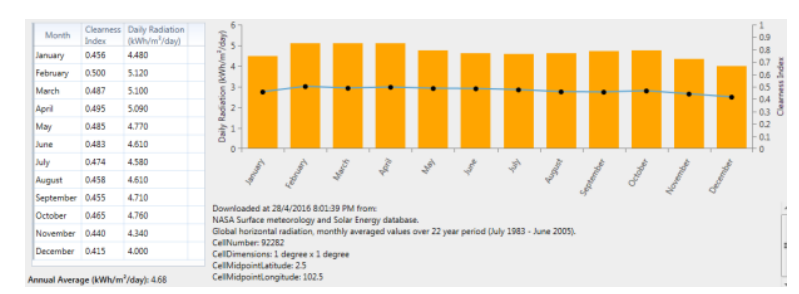

Fig. 6. Monthly Average Solar Global Horizontal Irradiance (GHI) Data.

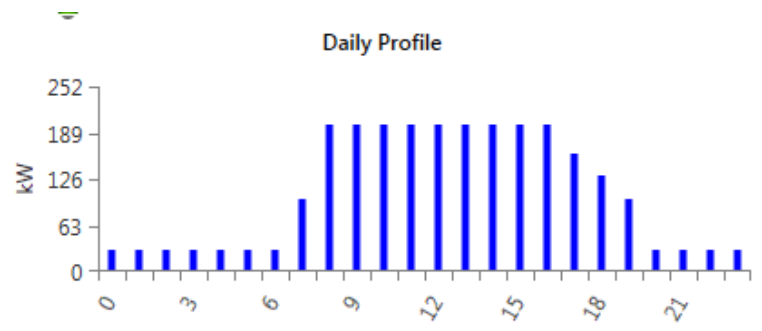

Fig. 7. Daily commercial load curve.

Furthermore, this study allows the estimation of the power delivery from the plant to consumers through simulating standard renewable plant. Since the area selected is considered a tourism site, thus the commercial electric load was chosen to simulate with the renewable plant $[13,14]$. The load rises in the morning and maintains until night time. After working hours, the load was at a minimum. Figure 7 shows the daily commercial load curve.

\section{B. Power Systems}

\section{1) Electric Grid}

In Malaysia, the electric tariff is fixed at a flat rate throughout the day by the government to reduce complication on the bill calculation. In this simulation, the price rate for buying and selling electricity to the grid was inserted to the Homer Pro Software to enable a more accurate simulation of the actual cost needed to implement this renewable energy plant. The price of the electricity per $\mathrm{kWh}$ was obtained from Tenaga National Berhad, a local electric utility company at the rate of 0.45 sen per $\mathrm{kWh}$ [15]. The rate of the selling price of the electricity of the renewable plan was obtained from SEDA portal which was 0.416 sen per $\mathrm{kWh}$ [16]. With the above information, the calculation of the cost was conducted.

2) Wind turbine farm

Wind turbine converts the kinetic energy from the wind into electrical energy. In order to calculate the power output of the wind turbine, we must first obtain the wind speed, $\mathrm{V}(\mathrm{t})$ at the desired height, hr, which is given by[17]:

$$
V_{(t)}=V_{r(t)} \times\left(\frac{h}{h_{r}}\right)^{r}
$$

The above $r$ is the power law exponent in the range of 0.14 to 0.25 . The output power of the wind turbine can be calculated 
with the wind speed obtained in equation (?). The output power of the wind turbine $\operatorname{Pwt}(\mathrm{t})$ is calculated by the following formula:

$$
P_{w t(t)}=\left\{\begin{aligned}
a v^{3}(t)-b P_{R}, & V_{c i}<V<V_{r} \\
P_{R}, & V_{r}<V<V_{c o} \\
0, & \text { Otherwise }
\end{aligned}\right.
$$

Where:

$$
\begin{aligned}
& a=\frac{P_{R}}{\left(V_{r}^{3}-V_{c i}{ }^{3}\right)} \\
& b=\frac{V_{c i}{ }^{3}}{\left(V_{r}{ }^{3}-V_{c i}{ }^{3}\right)}
\end{aligned}
$$

The rated power of the wind turbine is represented as Pr, while the cut-in wind speed, cut-out wind speed and the rated wind speed of the wind turbine is denoted by Vci, Vr and Vco. A Generic $10 \mathrm{~kW}$ wind turbine was chosen for our system and its wind turbine power curve is displayed in the Fig. 8.

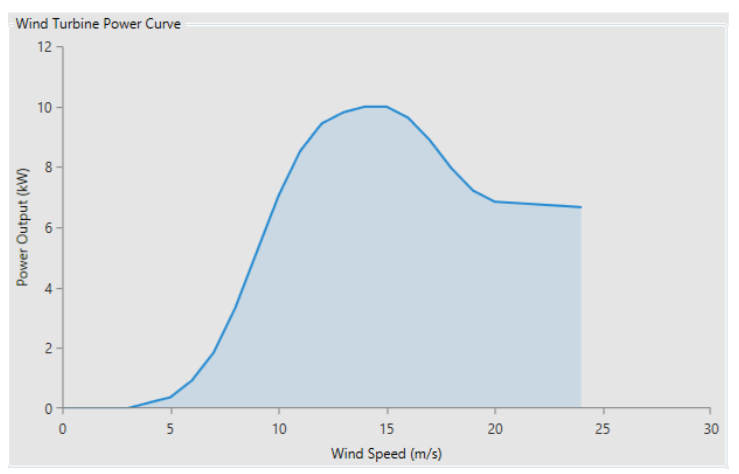

Fig. 8. Generic 10kW Wind Turbine Power Curve.

The various costs required for wind turbine implementation can be seen in Table II.

\section{3) Photovoltaic park}

The Solar option was added into consideration for the renewable energy plant as Malaysia is a country located near the equator. Besides that, Malaysia has only two seasons the entire year, which adds an advantage to solar farm as it receives sufficient and constant supply of sunlight throughout the year. PV or Photovoltaic cell is an equipment that transform solar energy into electrical energy. Inside a Photovoltaic panel consists of many photovoltaic cells arrange in both series and parallel to produce different voltage and current output required. The output of the PV panel can be increase or decrease through the presence of the solar irradiation and the surrounding temperature. The PV power output increases when the solar irradiation is high and reduces when the surrounding temperature increases [18]. During the design, the PV modules, the technical features, total power connected, total number of modules were considered to calculate the number of PV needed. After that, the subcomponents were considered such as, DC to AC converter. The peak power of the PV can be obtained in the equation below. TABLE III indicates the cost of PV needed in building the renewable energy plant.

$$
P_{C}=\frac{B_{j}}{N_{i n v} x E_{j}}
$$

$\mathrm{P}_{\mathrm{c}} \quad$ : Maximum power

$\mathrm{B}_{\mathrm{j}} \quad$ : Electricity for daily need (kWh)

$\mathrm{N}_{\text {inv }}$ : Inverter efficiency

$\mathrm{E}_{\mathrm{j}} \quad$ : Solar Irradiation $(\mathrm{kWh} / \mathrm{m} 2)$

Thus, the number of module can be obtained by:

$$
N_{\text {panels }}=\frac{P_{C}}{P_{\text {c units }}}
$$

TABLE II. MONTHLy AVERAGE Wind SPEEd DATA

\begin{tabular}{|c|c|c|c|c|}
\hline $\begin{array}{c}\text { Capacity } \\
(\mathbf{k W})\end{array}$ & $\begin{array}{c}\text { Capital } \\
(\mathbf{R M})\end{array}$ & $\begin{array}{c}\text { Replacement } \\
\text { (RM) }\end{array}$ & $\begin{array}{c}\text { Maintenance } \\
\text { Operation } \\
\text { (RM) }\end{array}$ & Quantity \\
\hline 10000 & 50000.00 & 15590.00 & $12,783.00$ & 1 \\
\hline
\end{tabular}

TABLE III. PRICE OF PV PANEL PER KW

\begin{tabular}{|c|c|c|c|c|}
\hline $\begin{array}{c}\text { Capacity } \\
(\mathbf{k W})\end{array}$ & $\begin{array}{c}\text { Capital } \\
(\mathbf{R M})\end{array}$ & $\begin{array}{c}\text { Replacement } \\
(\mathbf{R M})\end{array}$ & $\begin{array}{c}\text { Maintenance } \\
\text { Operation } \\
(\mathbf{R M})\end{array}$ & $\begin{array}{c}\text { Size } \\
(\mathbf{k W})\end{array}$ \\
\hline 1 & 1300.00 & 1300.00 & 13.00 & $0-2500$ \\
\hline
\end{tabular}

4) Inverter

An inverter was introduce to the system as the solar panels output was DC and the grid was AC. Therefore the inverter acts as a medium to transform and DC electric to AC electric and acts as the bridge for the two system. TABLE IV indicates the cost of inverter needed to build the renewable energy plant.

TABLE IV. PRICE OF INVERTER PER KW

\begin{tabular}{|c|c|c|c|c|}
\hline $\begin{array}{c}\text { Capacity } \\
(\mathbf{K W})\end{array}$ & $\begin{array}{c}\text { Capital } \\
(\mathbf{R M})\end{array}$ & $\begin{array}{c}\text { Replacement } \\
(\mathbf{R M})\end{array}$ & $\begin{array}{c}\text { Maintenance } \\
\text { Operation } \\
(\mathbf{R M})\end{array}$ & $\begin{array}{c}\text { Size } \\
(\mathbf{K W})\end{array}$ \\
\hline 1 & 1300.00 & 1300.00 & 13.00 & $0-2500$ \\
\hline
\end{tabular}

\section{Energetic and economic approach by HOMER pro}

This study was aimed to determine the appropriate types of renewable energy plant through the use of Homer Pro software at a chosen location. The plan for the plant was to supply the users surrounding Ayer Keroh using green energy. The software will be used to simulate and compare the wind and solar farm in terms of economic, energy and environmental aspects. Furthermore, the purpose of this comparison is to study the feasibility of green energy as the nation future power supply and also contribute to the fight against global warming and extreme climate changes. 


\section{Energy aspect}

The monthly load profile during the entire day is shown in Fig. 9. Since the chosen site was a tourism location, thus the loads are mostly on day time.

During the morning session, all the shops and offices operate during these hours and the loads were from air-conditioner, lighting and other appliances. The load peaks in the morning because that these appliances requires additional electricity to startup. The power production of both type of system is shown in Fig. 10a and Fig. 10b. Both Fig. 10a and Fig. 10b illustrates the fluctuation of the power output due to the changes to the input. The major impact to the input was normally caused by wind speed change, appearances of cloud for the wind turbine farm. However, the PV farm suffers from less fluctuation due to the equatorial climate of Malaysia where the amount of sunlight and temperature remains mostly constant during the day.The penetration level of both the two system can be seen in Fig. 11a and Fig. 11b. The penetration level was determined by the capability of the system to supply or electrify the load attached to the system [19].

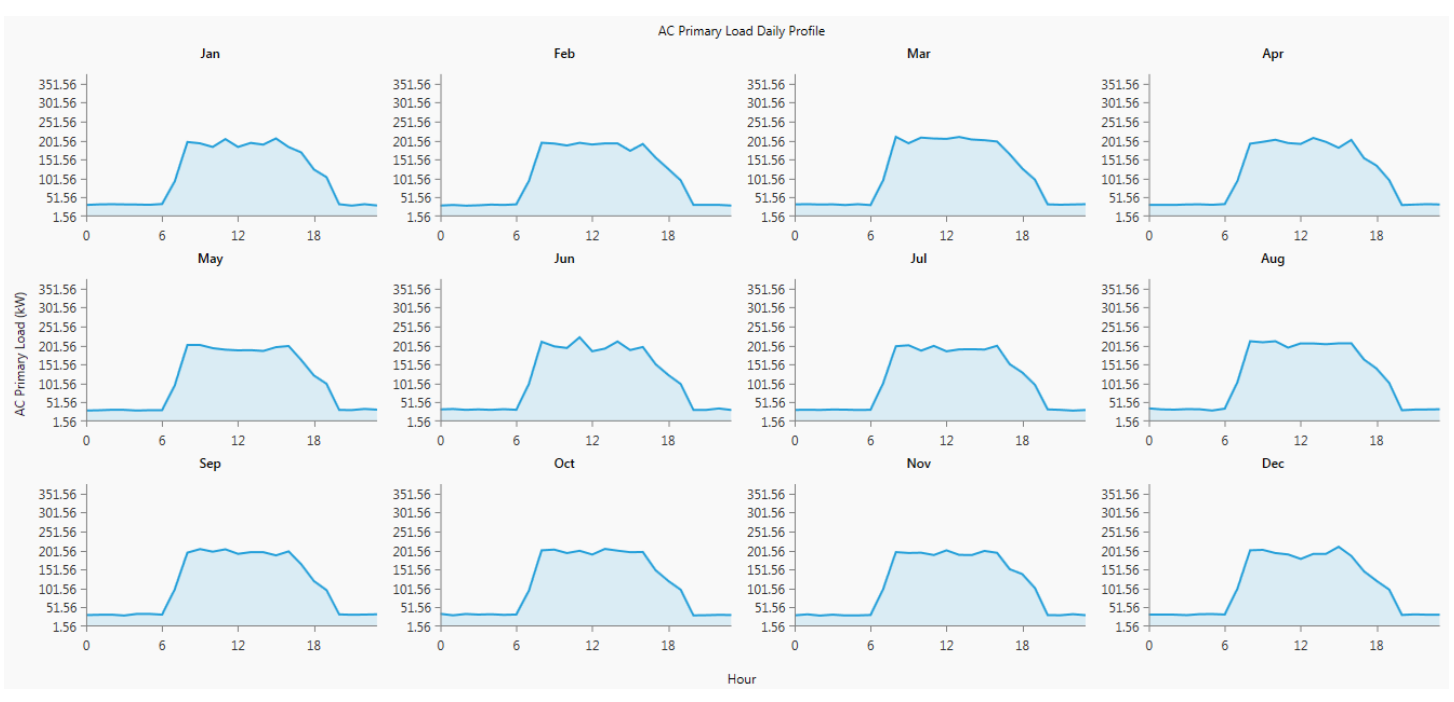

Fig. 9. Monthly load curve for commercial type

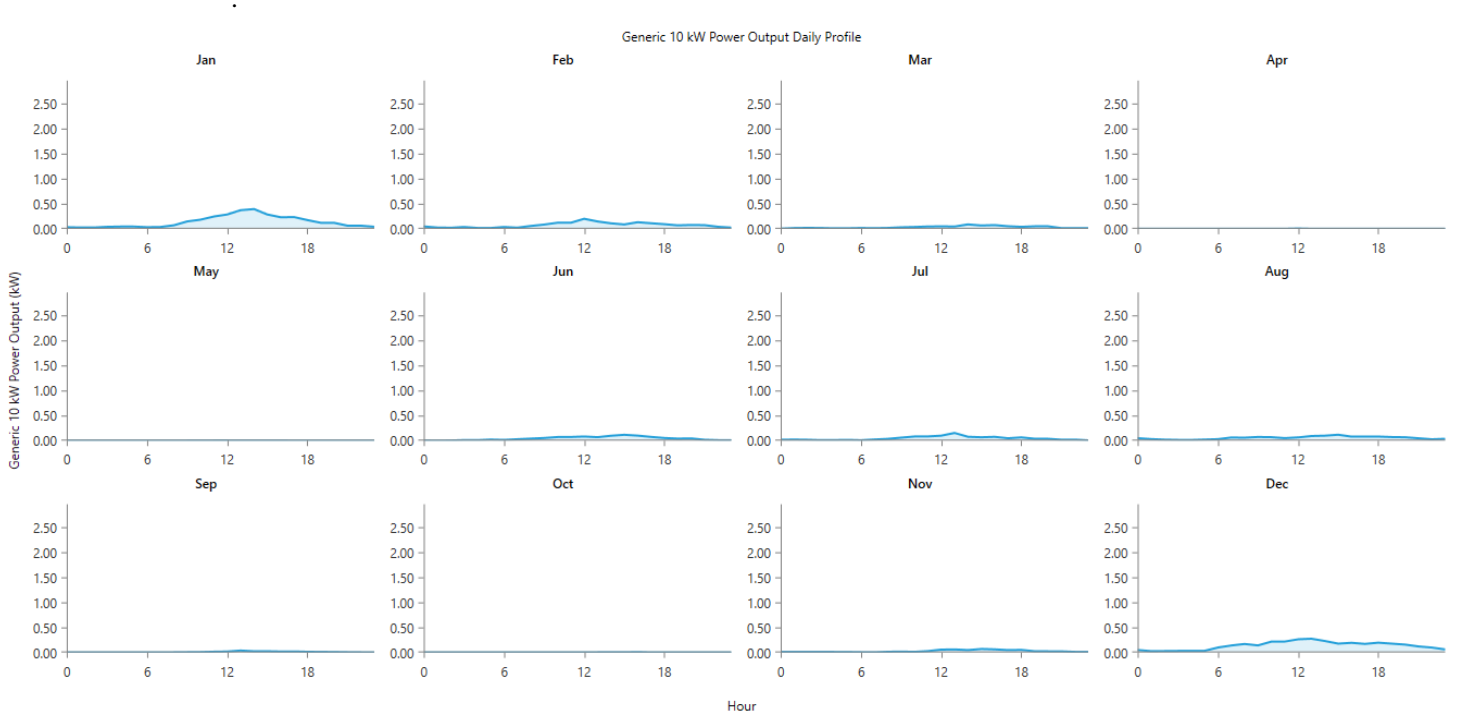

Fig. 10a. Generic 10kW wind turbine monthly power output. 


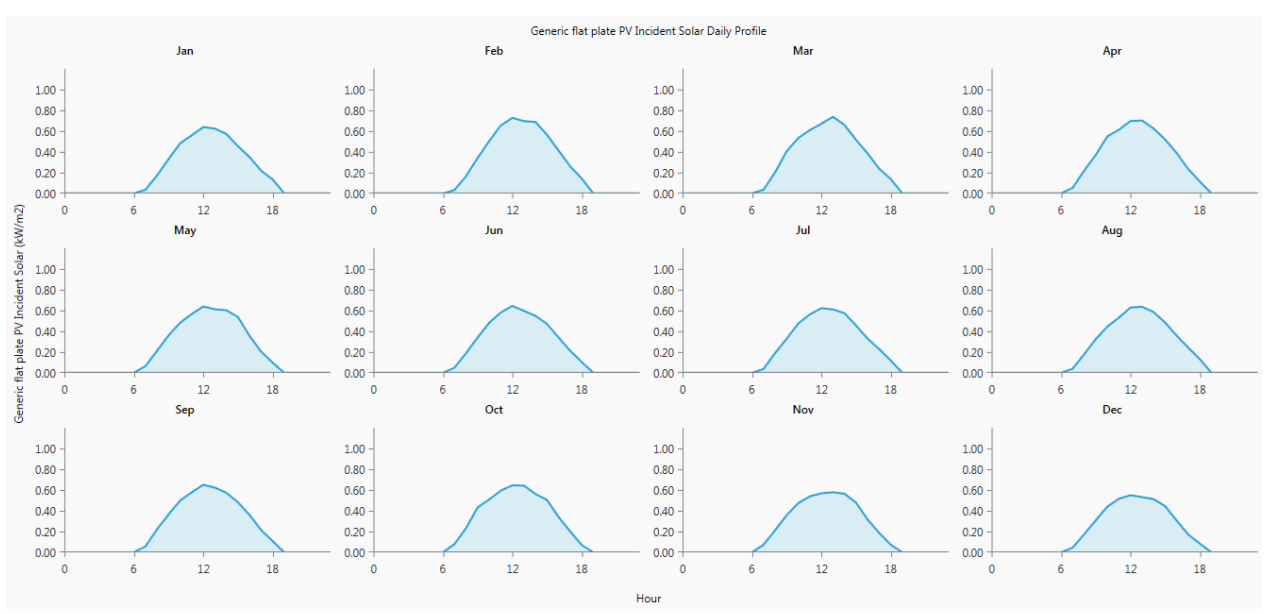

Fig. 10b. Generic flat plate PV monthly power output.
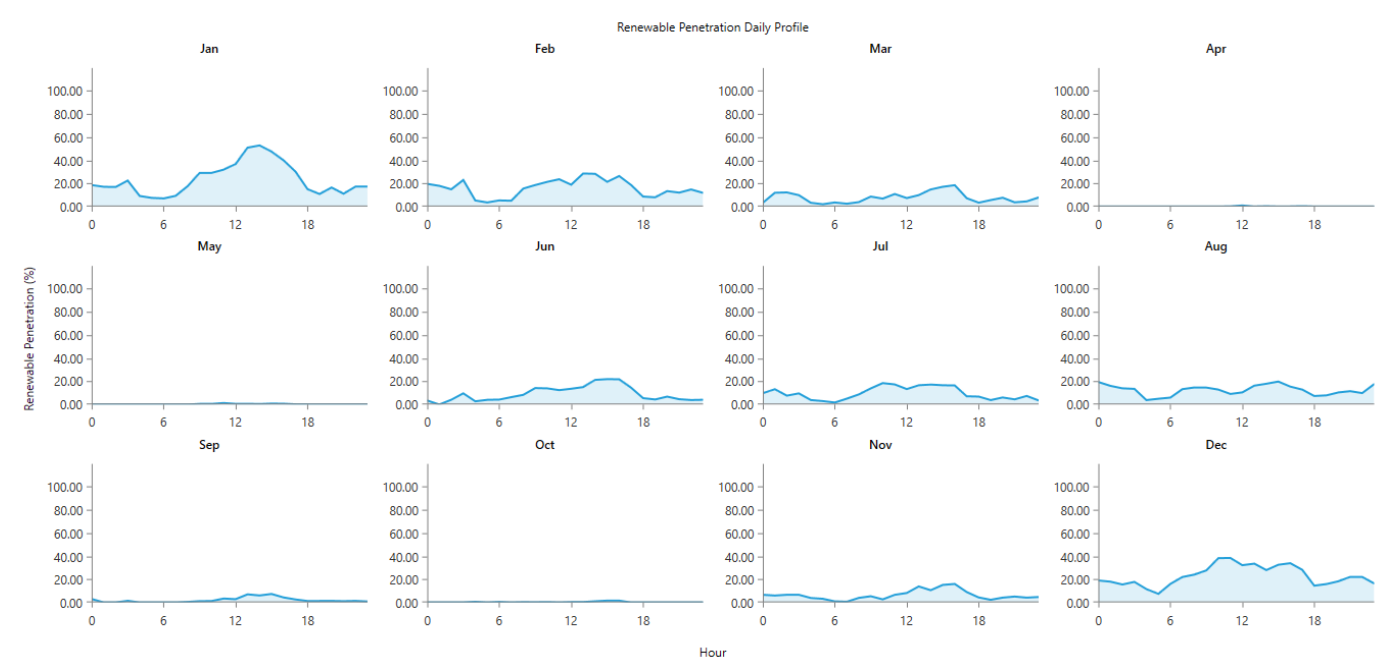

Fig. 11a. Wind Turbine renewable penetration monthly profile
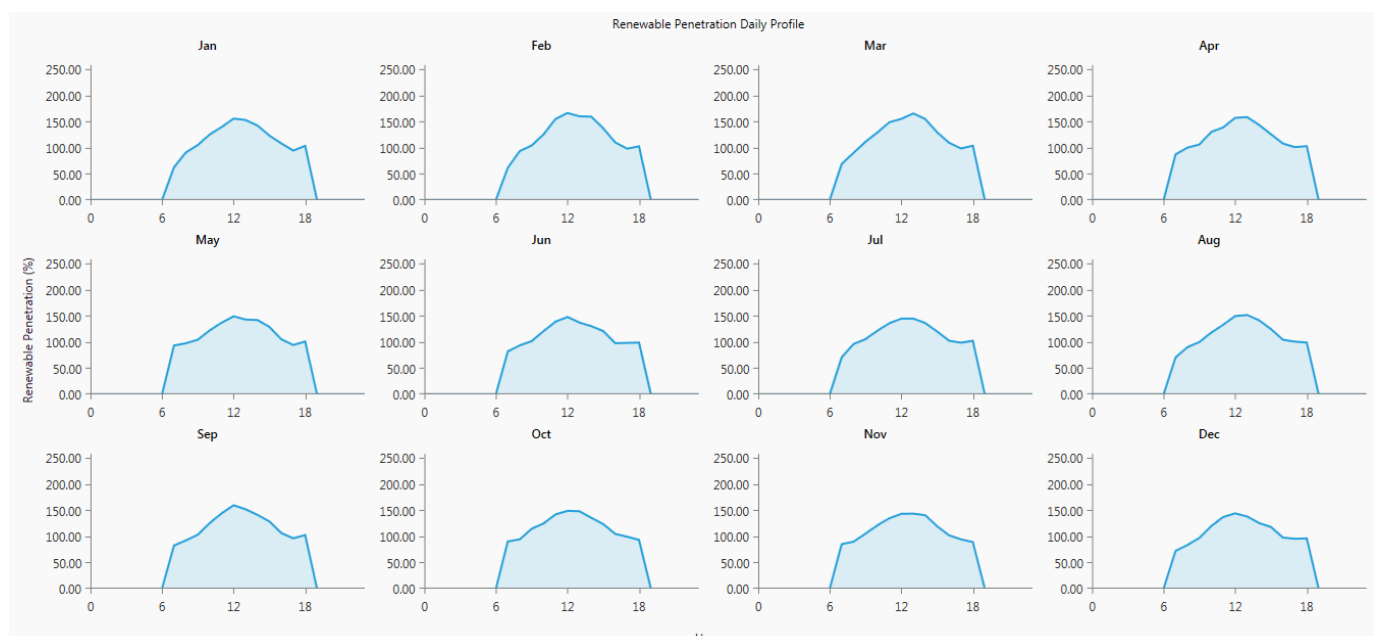

Fig. 11b. Solar renewable penetration monthly profile 
The rate of excess energy is the extra energy injected to the grid during the generation. Both Fig. 12a and Fig. 12b illustrate the level of excess energy produced during generation both two different system. Wind turbine was generating at a below average level, thus the system has no excess electricity. For the purchase and selling of electric energy with the grid were illustratited in Fig. 13a, Fig. 13b and Fig. 14a, Fig. 14b for both wind and solar respectively. The rate of power exchage were recorded in the diagrams below which include both type of renewable energy system. Table V and VI illustrate the cost of implementing two type of energy farm such as the wind turbine and Photovoltaic farm through Homer Pro software.

Between the two systems, the cost of installation for the PV farm is higher than the wind turbine farm by a large margin. Even though that it is cheaper to operate and maintain a wind turbine farm, it is not appropriate to install it in Ayer Keroh, Melaka where the wind speed is too low to spin the wind turbine. The average speed of the wind in Ayer Keroh is $2.45 \mathrm{~m} / \mathrm{s}$ but the wind turbine requires a minimum $3 \mathrm{~m} / \mathrm{s}$ to operate. Since Malaysia's climate is equatorial, PV farm is more suitable to operate long term due to having a relatively constant amount of sunlight available during the day. TABLE VII and TABLE VIII show the gas emission of two of the designed system during off peak hours.

\begin{tabular}{|l|l|l|}
\hline Quantity & $\mathrm{kWh} / \mathrm{yr}$ & $\%$ \\
\hline Excess Electricity & 0.0 & 0.0 \\
Unmet Electric Load & 0.0 & 0.0 \\
Capacity Shortage & 0.0 & 0.0 \\
\hline
\end{tabular}

Fig. 12a. Wind turbine level of excess electrical production.

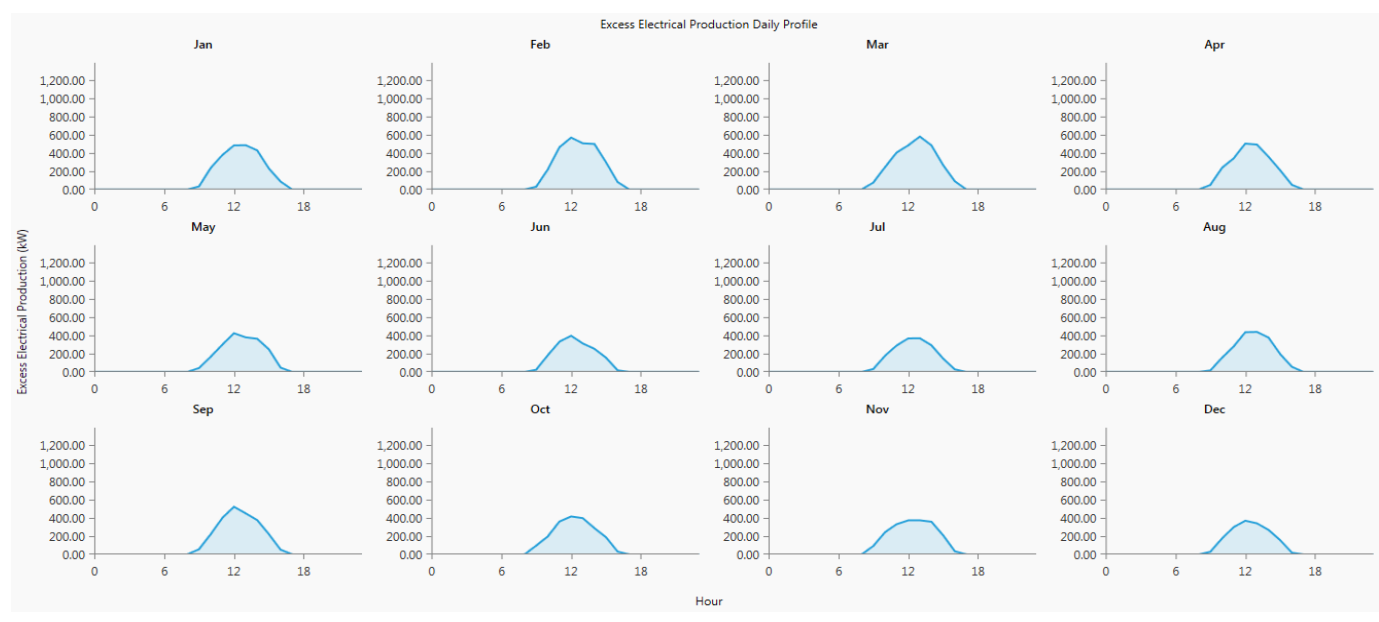

Fig. 12b. Solar level of excess electrical production.
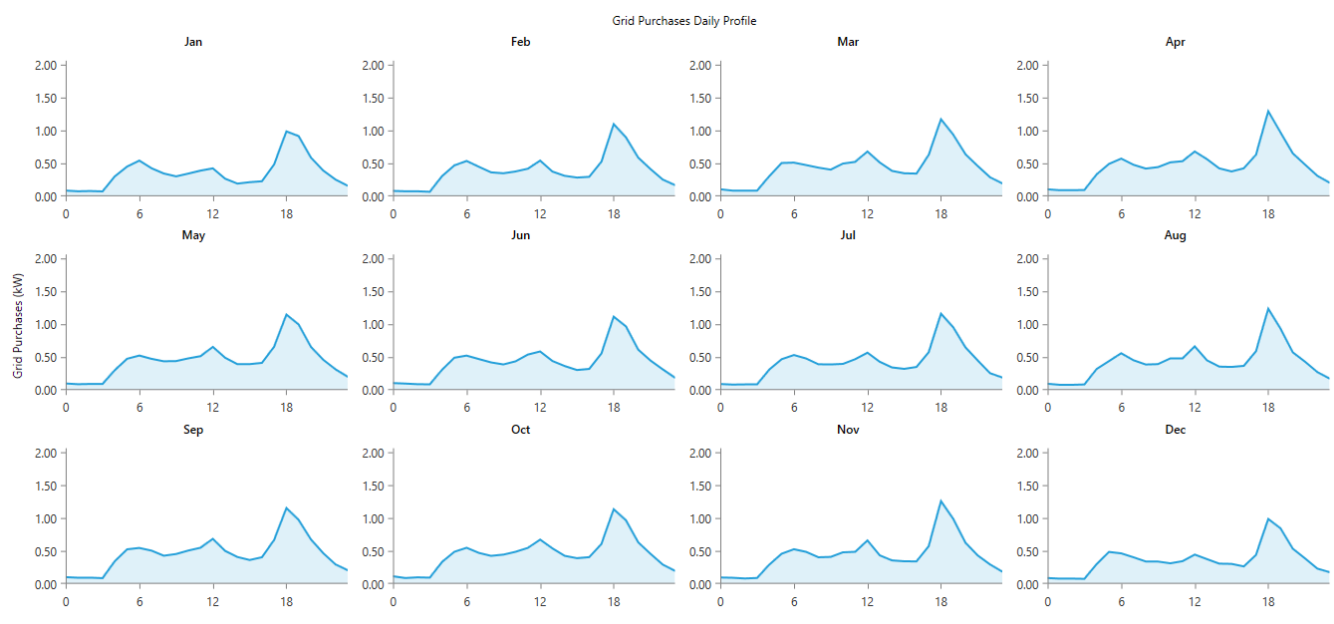

Fig. 13a. Energy purchased from the grid for the wind turbine system 

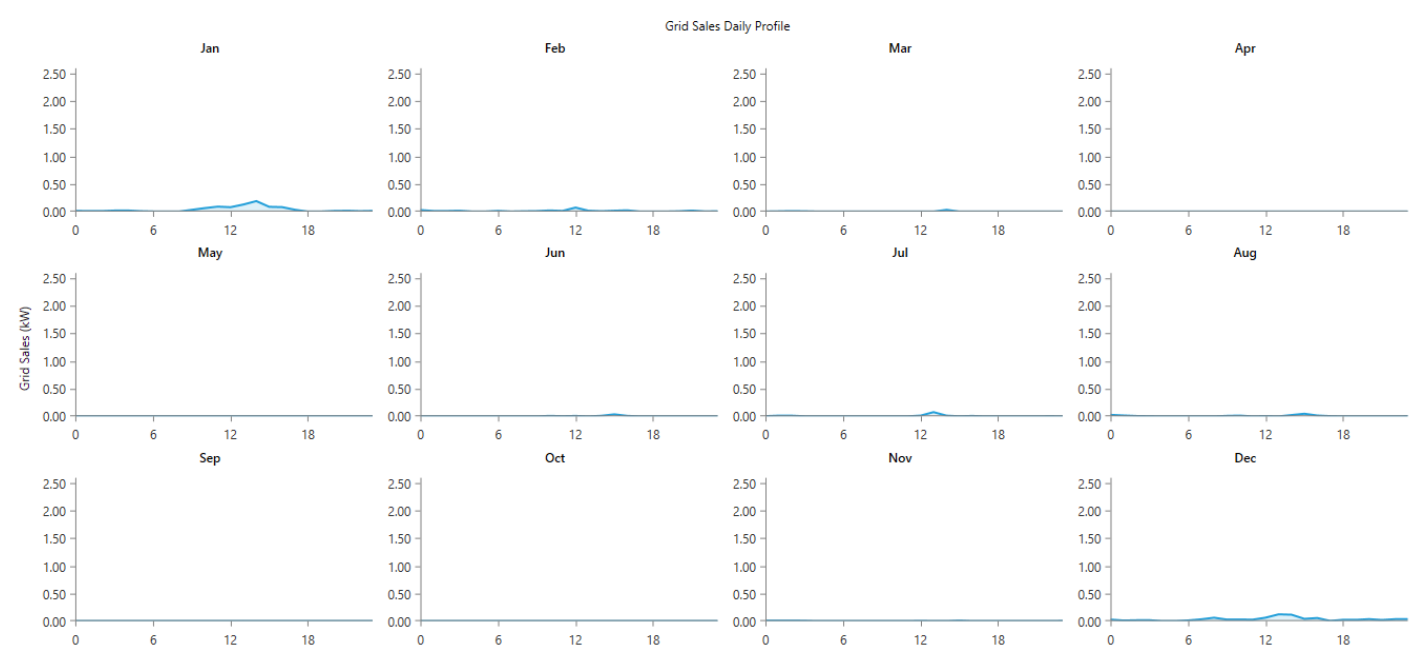

Fig. 13b. Energy sold to the grid for the wind turbine powered system
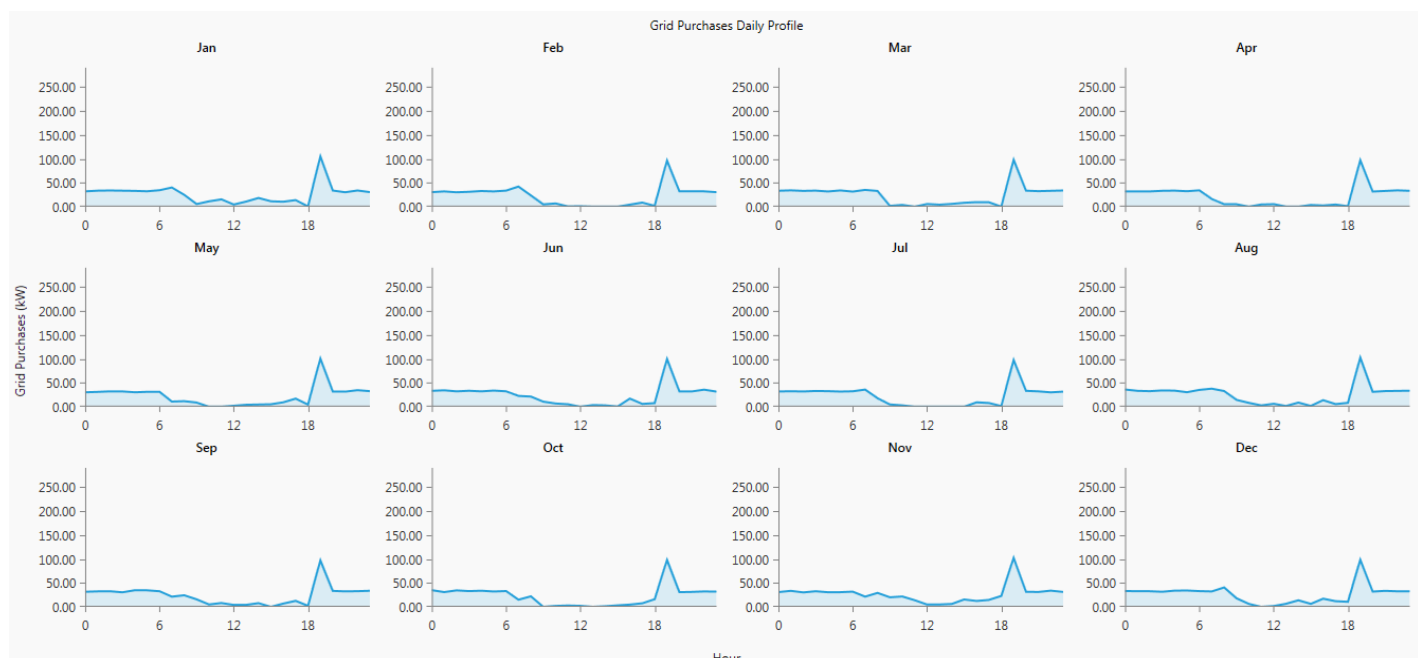

Fig. 14a. Energy purchased from the grid for the solar powered system
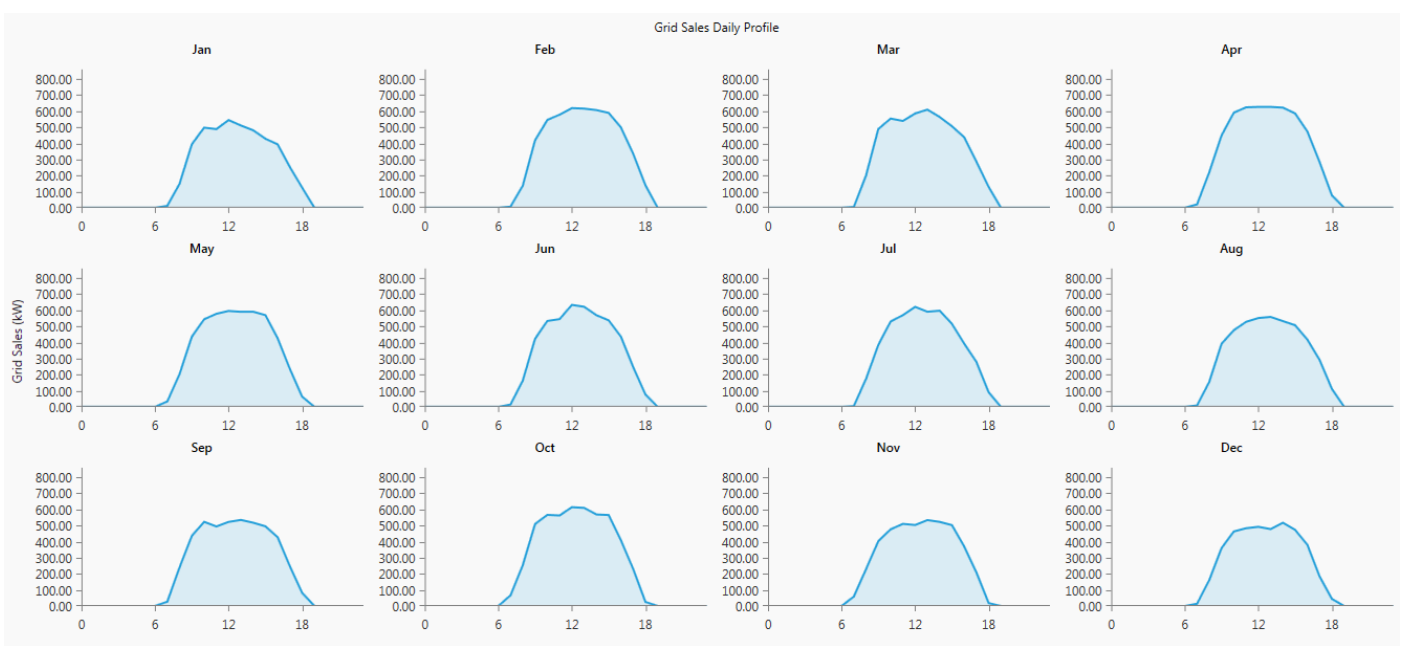

Fig. 14b. Energy sold to the grid for the solar powered system 
TABLE V. C COST NEEDED FOR INSTALLATION OF WIND TURBINE FARM

\begin{tabular}{|c|c|c|c|c|c|}
\hline Device & Capital (RM) & Replacement(RM) & $\begin{array}{c}\text { Operation and } \\
\text { Maintenance(RM) }\end{array}$ & Salvage(RM) & Total(RM) \\
\hline $\begin{array}{c}\text { Generic } \\
\text { wind } \\
\text { turbine }\end{array}$ & $50,000.00$ & $15,590.00$ & $12,783.00$ & $8,737.50$ & $69,636.00$ \\
\hline Grid & 0.00 & 0.00 & $10,147.00$ & 0.00 & $10,147.00$ \\
\hline System & $50,000.00$ & $15,590.00$ & $22,930.00$ & $8,737.50$ & $79,783.00$ \\
\hline
\end{tabular}

TABLE VI. COST OF INSTALLATION NEEDED FOR PV FARM

\begin{tabular}{|c|c|c|c|c|c|}
\hline Device & Capital (RM) & Replacement(RM) & $\begin{array}{c}\text { Operation and } \\
\text { Maintenance(RM) }\end{array}$ & Salvage(RM) & Total(RM) \\
\hline $\begin{array}{c}\text { Generic flat } \\
\text { PV }\end{array}$ & $7,307,343.00$ & 0.00 & $424,146.00$ & 0.00 & $7,731,490.00$ \\
\hline Grid & 0.00 & 0.00 & $10,807,729.00$ & 0.00 & $10,807,729.00$ \\
\hline Converter & $270,000.00$ & $350,398.00$ & 0.00 & $64,477.00$ & $555,921.00$ \\
\hline System & $7,577,343.00$ & $350,398.00$ & $10,383,585.00$ & $64,477.00$ & $2,520,391.00$ \\
\hline
\end{tabular}

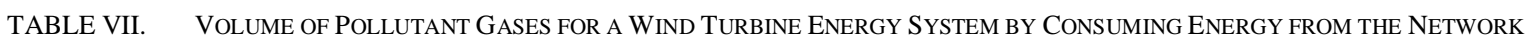

\begin{tabular}{|c|c|}
\hline Gas & Emission $(\mathbf{k g} / \mathbf{y r})$ \\
\hline Carbon dioxide & 235,463 \\
\hline Carbon monoxide & 0 \\
\hline Sulfur dioxide & 1,804 \\
\hline Nitrogen dioxide & 958 \\
\hline
\end{tabular}

TABLE VIII. VOLUME OF POLLUTANT GASES FOR A SOLAR ENERGY SySTEM By CONSUMING ENERGy FROM THE NETWORK

\begin{tabular}{|c|c|}
\hline Gas & Emission $\mathbf{( k g} / \mathbf{y r})$ \\
\hline Carbon dioxide & $-950,524$ \\
\hline Carbon monoxide & 0 \\
\hline Sulfur dioxide & $-4,121$ \\
\hline Nitrogen dioxide & $-2,015.4$ \\
\hline
\end{tabular}

\section{IV.CONCLUSION}

A comparison between a wind turbine farm and a photovoltaic farm has been carried out in this journal in order to determine its feasibility based on both efficiency and also emission rates. Both these simulated scenarios have their systems connected to the grid and both housing and commercial area of Ayer Keroh, Melaka. Based on the results, a photovoltaic farm is definitely at a better technoeconomical state compared to wind turbine. The wind turbine is not efficient enough to be able to produce energy in this regard as the average wind speed is below the necessary requirements for spinning the blades of the wind turbine. This is not the case for the photovoltaic farm as it suffers from less fluctuation due to the equatorial climate of Malaysia where the amount of sunlight and temperature remains mostly constant during the day. The photovoltaic farm system also generates enough excess to the grid, allowing an increase in return of investment.

\section{REFERENCES}

[1] Md. Aaju Ahmed, Subir Ranjan Hazra, Md. Mostafizur Rahman, Rowsan Jahan Bhuiyan, "Solar-biomass hybrid system: Proposal for rural electrification in bangladesh", Electrical and Electronics Engineering: An international journal vol 4, no 1, february 2015

[2] S. goel, S. majid ali, ," "Feasibility study of hybrid energy systems for remote area electrification in odisha, india by using homer ${ }^{\text {eee }}$, International Journal of Renewable Energy Research, Vol3, no. 3.

[3] Essam A. Al-Ammar, Nazar H. Malik, Mohammad Usman, "Application of Using Hybrid Renewable Energy in Saudi Arabia, Engineering", Technology \& Applied Science Research Vol. 1, N 4 , 2011, 84-89.

[4] GM Shafiullah, Amanullah M.T. Oo , ABM Shawkat Ali , Dennis Jarvis , Peter Wolfs, "Economic Analysis of Hybrid Renewable Model for Subtropical Climate", International journal of Thermal and Environmental Engineering Volume 1, No. 2 (2010) 57-65. 
[5] Pragya Nema, Sayan Dutta, "Feasibility Study of 1 MW Standalone Hybrid Energy System: For Technical Institutes", Scientific research 2012, p 63-68

[6] J. B. Fulzele, Subroto Dutt, "Optimium Planning of Hybrid Renewable Energy System Using HOMER", International Journal of Electrical and Computer Engineering (IJECE) Vol. 2, No. 1, February 2012, pp. 68 74

[7] Smruti Ranjan Pradhan, Prajna Pragatika Bhuyan, Sangram Keshari Sahoo, G.R.K.D.Satya Prasad, "Design of Standalone Hybrid Biomass \& PV System of an Off-Grid House in a Remote Area", Smruti Ranjan Pradhan et al Int. Journal of Engineering Research and Applications, Vol. 3, Issue 6, Nov-Dec 2013, pp.433-437.

[8] "Melaka and George Town, Historic Cities of the Straits of Malacca," UNESCO, 2013.2 [Online]. Available: http://whc.unesco.org/en/list/1223. [Accessed 28 April 2016].

[9] T. C. LI, "Solar farm boosts Malaysia's renewable energy supply," The Star Online, [Online]. Available: http://www.thestar.com.my/lifestyle/features/2015/03/09/solar-farmboosts-malaysias-renewable-energy-supply/. [Accessed 28 April 2016].

[10] "Google Maps," Google, [Online]. Available: https://www.google.com.my/maps/place/75450+Ayer+Keroh,+Malac ca/@2.2739628,102.2803193,14z/data=!4m7!1 m4!3m3!1 s0x0:0x0!2 zMsKwMTYnMDkuNSJOIDEwMsKwMTcnMjkuMyJF!3b1!3m1!1s 0x31d1e572dbf414d3:0x53f464b4e13621ae?hl=en. [Accessed 28 April 2016].

[11] "Malaysia, Asia," Greenwich2000.ltd.uk, [Online]. Available: http://wwp.greenwichmeantime.com/time-zone/asia/malaysia/. [Accessed 28 April 2016].

[12] "Malaxi," Melaka Map ( Malacca )- Location, City, Road, Street, Direction, Highway map, [Online]. Available: http://www.malaxi.com/map_melaka.html. [Accessed 28 April 2016].

[13] "AIR KEROH TOURIST ATTRACTION MAP," Melaka.net, [Online]. Available: http://www.melaka.net/ak_touristmap.htm. [Accessed 01 May 2016].

[14] "Ayer Keroh Attractions," Malacca, [Online]. Available: http://www.malacca.ws/ayer-keroh/attractions.htm\#. [Accessed 01 May 2016].

[15] "BILL CALCULATOR," Tenaga National, [Online]. Available: https://www.tnb.com.my/residential/billing. [Accessed 1 May 2016].

[16] "FiT Rates for Solar PV (Non-individual (> $500 \mathrm{~kW})$ ) (21 years from FiT Commencement Date)," Sustainable Energy Development Authority of Malaysia (SEDA Malaysia), [Online]. Available: http://seda.gov.my/. [Accessed 1 May 2016].

[17] M. Farshid and S. Hossein, "Feasibility and Optimal Reliable Design of Renewable Hybrid Energy System for Rural Electrification in Iran," International Journal of Renewable Energy Research, vol. 2, no. 4,2012 .

[18] M. Mohammed, A. Aziz, A. H. A. Alwaeli and H. A. Kazem, "Optimal Sizing of Photovoltaic Systems using HOMER for Sohar, Oman,," International Journal of Renewable Energy Research, vol. 3, no. 3, 2013.
[19] K. E. Okedu and R. Uhunmwangho, "Optimization of Renewable Energy Efficiency using HOMER," International Journal of Renewable Energy Research, vol. 4, no. 2, 2014.

[20] J. G. Fantidis, D. V. Bandekas, C. Potolias and N. Vordos, "The Effect Of The Financial Crisis On Electricity Cost For Remote Consumers: Case Study Samothrace (Greece)," International Journal Of Renewable Energy Research, vol. 1, no. 4, pp. 281-289, 2011.

[21] W. Chadha and K. Lotfi, "Study and design of a hybrid production unit for island Kerkennah," research master in power conversion and renewable energy, 2013.

[22] S. Goel and S. M. Ali, "Cost Analysis of Solar/Wind/Diesel Hybrid Energy Systems for Telecom Tower by Using HOMER,"

International Journal of Renewable Energy Research, vol. 4, no. 2, 2012. 